\title{
Factors that Affect the Use of the Online Payment System on E-Commerce (Case Study on Users of Shopee.CO.ID)
}

\author{
Triyani Budyastuti \\ Accounting Study Program, Faculty of Economics and Business, University of Mercu Buana \\ Jl. Raya Meruya Selatan Kembangan West Jakarta
}

\begin{abstract}
This study aims to examine the effect of Usefulness, Easy of Use, and E-Commerce Trust on Buying Decisions. The population and samples in this study were 100 respondents who had used shopee.co.id. Data analysis method uses multiple linear regression analysis. The results of this study indicate that there is an influence of Usefulness, Ease of Use, and Trust on User Behavior on shopee.co.id consumers
\end{abstract}

Keywords: Usefulness, Ease of Use, Trust, User behavior

DOI: $10.7176 / \mathrm{IKM} / 9-5-03$

Publication date:May $31^{\text {st }} 2019$

\section{INTRODUCTION}

The rapid development of information technology has a positive impact on all things, one of which is providing convenience to various aspects of the business. Many transactions in the business environment are currently being transferred to electronic networks. The network can be very small and only involve computers in a single business, or it can be so large that it covers the entire world. Electronic networks are groups of computers that are electronically interconnected, so companies are able to conventionally assemble transaction data and distribute information as long as the diversity of locations. E-Commerce is a process of buying and selling products electronically by consumers and from companies to companies with computers as an intermediary for business transactions. E-Commerce or commonly referred to as Ecom or Emmerce or EC is a routine business exchange using the transmission of Electronic Data Interchange (EDI), e-mail, electronic bulletin boards, facsimile machines, and Electronic Funds Transfers relating to shopping transactions on internet shopping, Electronic Commerce (E-Commerce) describes a wide range of technologies, processes and practices that can make transactions without using paper as a means of transaction mechanism.

E-Commerce has a major influence on the social and economic growth of society. E-Commerce has become an important part of the private business sector (private) and general (public). This is indeed highly recognized because with this E-Commerce, operational costs can be reduced to compete with the increasing number of requests that require fast and accurate services. This is a symptom of the rapid development of social information.

A number of reports state that with the Indonesian population which according to the World Bank in 2013 reached 249.9 million and the number of internet users according to the Ministry of Communication and Information (Kemenkominfo) in 2014 which reached 82 million or equivalent to the 8th rank in the world, Indonesia became one of the biggest developing countries with e-commerce potential in the world besides China, India, Brazil and Russia. Data from the ICD research institute predicts that the e-commerce market in Indonesia will grow 42 percent in 2012-2015. This figure is higher than other countries such as Malaysia (14\%), Thailand (22\%), and the Philippines (28\%). Meanwhile, based on the Bolton Consulting Group (BCG) data, in 2013 the middle class in Indonesia had reached 74 million and was predicted by 2020, this figure had risen to 141 million people or around 54 percent of the total population in Indonesia (www .sp.beritasatu.com).

The Minister of Communication and Information estimates that e-commerce sales transactions reach US $\$ 25$ or around 312 trillion by the end of 2015. This estimate is up from 2014 which reached 12 billion US, equivalent to 150 trillion. E-commerce business transactions or online shopping are increasing every year. Ecommerce will become the future business model in Indonesia along with the growth of internet users in Indonesia, which has reached 88 million people or an increase of more than 10 percent compared to the previous year (www.republika.co.id).

The following is a graph of the market value of e-commerce in Indonesia which continues to increase from year to year 


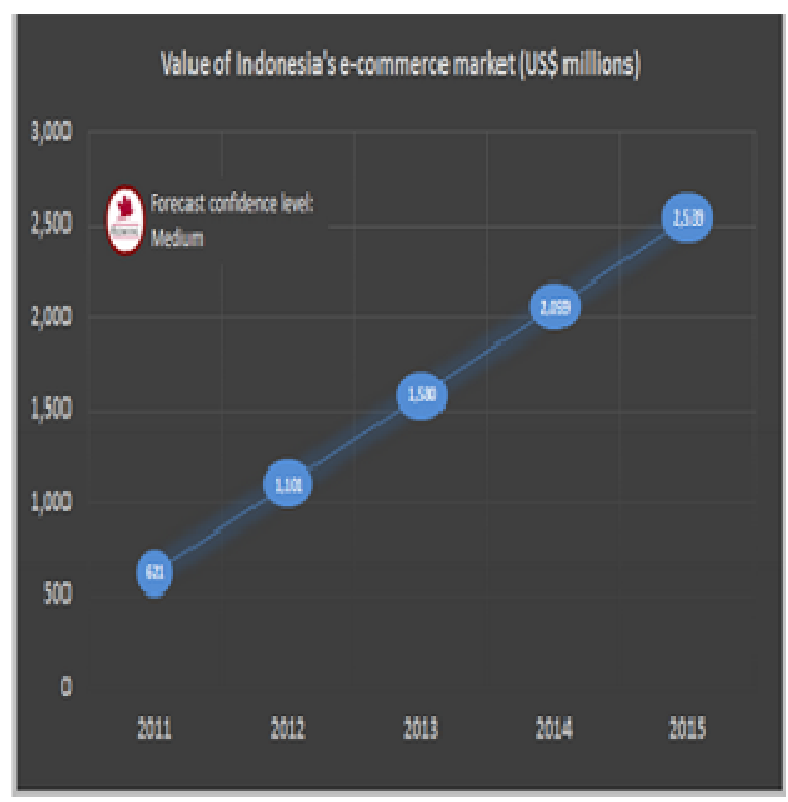

Pigure 1: E-commerce Market Value

Chart Source: www.dailysocial.net

The graphic image above shows the market value of e-commerce in Indonesia for 2015 has reached \$2,539. The growth of e-commerce business transactions or online shopping is increasing every year, proving that Indonesians are very interested in shopping at online stores. They can easily access the website and carry out buying and selling transactions online.

E-commerce business in Indonesia has grown quite well in 2017. Google's Temasek research results, noted that e-commerce sales figures will reach USD 10.9 billion, skyrocketing $41 \%$ from the USD 5.5 billion figure in 2015.

Badan Koordinasi Pasar Modal (BKPM) revealed that the value of investment in the e-commerce sector in 2017 reached more than USD 5 billion. E-commerce business is now the most strategic economic sector and will still be the prima donna of investors in 2018 .

This growth is influenced by the pattern of public spending which shifts to online trading, especially the use of mobile applications for shopping.

The evolution that occurs in shopping applications in Indonesia has affected our daily lives. Security aspects, product completeness, and practicality are often the main reasons when choosing a marketplace compared to shopping online for others. Moreover, the promos given by each e-commerce company increasingly influence the decisions of buyers in choosing e-commerce platforms. For those who often shop at online applications, they must be familiar with the promos given by each e-commerce company.

Based on the data ranking of mobile shopping applications (Google Play and App Store) every week from Appnie from January to December 2017, there are data ranking of the top five mobile applications based on the average ranking in each quarter

The details are:

1. Shopee won achievement as number 1 mobile application

2. Blibli who dominates Twitter and Facebook

3. Increased zalora

4. Tight competition between Lazada and Tokopedia

5. Hijup is still the queen of Instagram

The growth of the e-commerce sector is in fact also making business in retail outlets in Indonesia shift their business from offline to online. Not a few of the online shop on Instagram also switch to selling to e-commerce platforms like Shopee.

This is because the e-commerce platform has an Instashop X Shopee photo, which allows traders on Instagram to enter the products they sell on social media to their accounts on e-commerce.

As a player who is still relatively new in e-commerce Indonesia, Shopee's business has grown quite consistently, as a result of their efforts to minimize the distance with other e-commerce players who have been playing for a long time in Indonesia. Shopee experienced significant growth in its seven markets, with annualized Gross Merchandise Value (GMV), more than USD 5 billion and around 80 million downloads throughout the region.

Based on expert research concluded by Kim et al (2008) shows that the intention to use an e-commerce 
system is driven by trust which has an important role in increasing the usefulness of e-commerce systems. To achieve the objectives of this research, the researcher develops a concept model. In developing this concept model the variables of usability, convenience and trust are independent variables that influence the dependent variable, namely online purchasing decisions.

Another result of the research conducted by Denni Ardyanto (2015) where the results of his research show that convenience significantly influences online purchasing decisions, trust has a significant effect on online purchasing decisions, ease and trust in using e-commerce has a significant effect on simultaneous online purchasing decisions. The results of the analysis can be seen that with ease in the process of operating transactions affect consumers to use e-commerce services.

\section{Problem Formulation}

Problem formulation from this research are as follows:

1. Is there a perceived usefulness effect on user behavior?

2. Is there an effect of perceived ease of use on user behavior?

3. Is there an influence of trust in user behavior?

\section{Research purposes}

The purpose of this research is to prove and test empirically about:

1. The effect of perceived usefulness on user behavior

2. Effect of perceived ease of use on user behavior

3. Effect of trust in user behavior

\section{LITERATUR RIVIEW}

\section{Technology Acceptance Model (TAM)}

According to Davis (1986) the behavior of using Information Technology (IT) begins with the perception of the benefits (usefulness) and perceptions about the ease of using IT (ease of use). These two elements when associated with TRA are part of Belief. Davis (1986) defines the perception of usefulness based on the definition of useful words, namely capable of being used advantageously, or can be used for profitable purposes. Perception of usefulness is a benefit that is believed by individuals that can be obtained when using IT.

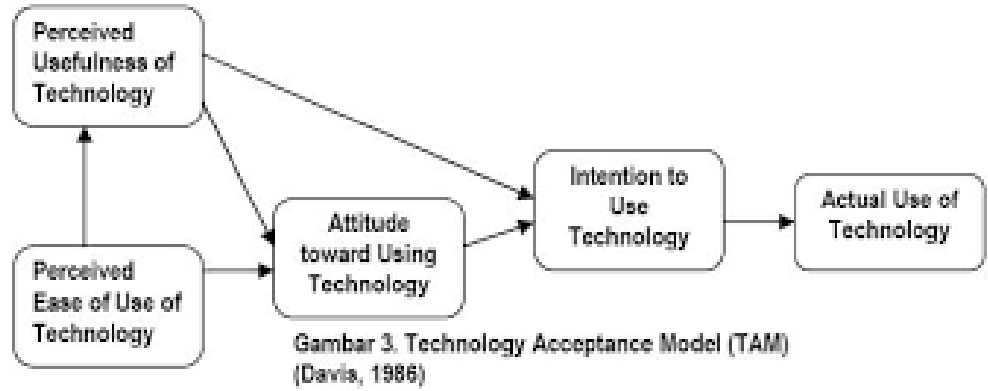

Figure 2: Model TAM

Sources: Davis (1986)

Unified Theory of Acceptance and Use of Technology (UTAUT)UTAUT developed by Venkatesh, et al. (2003) combining features from several theories of acceptance of leading technology into one theory. The results of testing these models finally recommend four variables as determinant of the purpose and use of information technology, namely performance expectations (performance expectancy), business expectations (social expectancy), social influences (Social Influence), and supporting conditions (Facilitating Conditions), and four variables as moderators (moderating variables) between determinants with the purpose and use of information technology, namely gender, age, experience, and voluntariness (compulsory or not using an information system at work) 


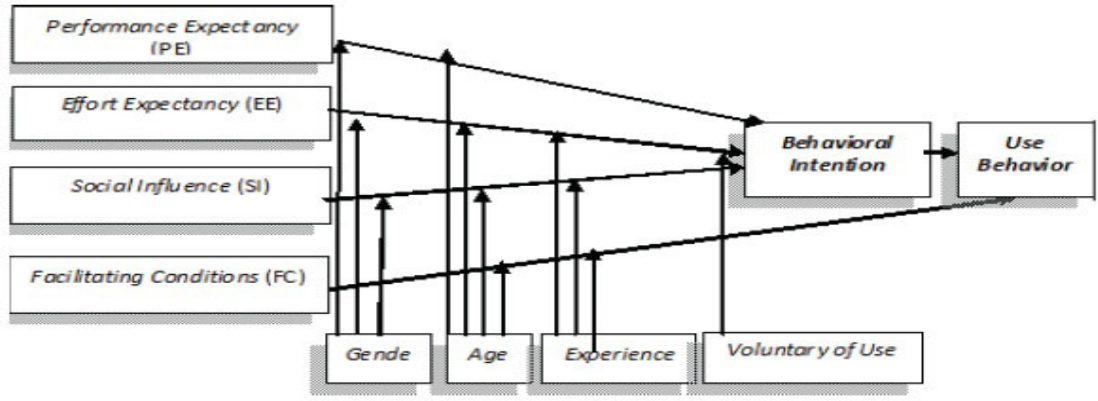

Figure 3: Model UTAUT I

Source: Venkatesh et al.,(2003)

Perceived Usefulness: Perceived Usefulness technology is definedas the level at which someone believes that using a particular system willimprove work performance (Diane, 2008). Thus if someonefeeling confident that the information system is useful then he will use it.Conversely if someone feels that the information system is not usefulthen he won't use it. (Idrith, 2010)

Perceived ease of use: Perceived perceived ease of use technology is defined as the level at which someone believes that using a particular system will be free of workload, so that someone feels that when the information system is easy to use, he will use it. Conversely, if someone feels confident that the information system is not easy to use then hewill not use it. (Zeinab et al., 2015)

Trust: Trust is the foundation of business. A business transaction between two or more parties will occur if each trusts one another. These trusts cannot be recognized by other parties / business partners, but must be built from the beginning and can be proven. Trusts have been considered as catalysts in various transactions between sellers and buyers so that customer satisfaction can be realized as expected. (Yousafzai et al., 2003)

Electronic Payment Syste: An electronic payment system or abbreviated e-payment is part of an e-commerce transaction that aims to facilitate the process of selling and buying via the internet. In general, electronic payments in the context of e-commerce refers to online transactions conducted through the internet, although there are many other forms of electronic payments (American education, 2012; Armesh et al., 2010). The electronic payment system is a solution for merchants to provide payment options online through the internet for their consumers. Electronic payments can also be defined as the process of payments made without using paper instruments (Tella, 2012).According to Laudon \& Traver (2011), electronic or digital payment systems consist of:

- Online credit card transactions, is the main form in the online payment system. The parties involved in the payment process use online credit cards, namely consumers, merchants, clearinghouses, merchant banks (acquirers) and consumer banks (issuers).

- Digital wallets, are digital wallets that can store personal information and other important information in various forms.

- Digital Cash, is an online token (numeric) based on a bank where consumers save funds or credit card accounts.

- Online stored value systems, a system that allows consumers to make online and instant payments to merchants or other individuals based on the value stored in online accounts. Consumers only need to sign up and send money to the online account.

Behavior: Behavior is an action taken by someone. Factors that influence behavior both from the individual and from outside the individual will not form a certain behavior if the individual concerned does not have an interest in doing this behavior.A person's behavior is determined by his interests. interest is the best predictor of behavior. If you want to know what someone is going to do, the best way to predict it is to know the person's intentions / interests.

Skiner in Soekidjo Notoatmojo said that behavior is formed from two main factors, namely: a stimulus which is a factor of individual personality (external factors) and a response that is a factor of the individual concerned (internal factors). External factors or stimuli are environmental factors, both physical and nonphysical in the form of social, cultural,economy, politics and so on, while internal factors include attention, observation, perception, motivation, fantasy, suggestion and so on. However, actual behavior is a whole (totality) of one's understanding and activity which is a shared result between internal factors and external factors.Preliminary

\section{Study Framework}

Perceived Usefulness in this study is a perception that a user has that online payment services that he uses will bring benefits to himself. This benefit is in the form of support to users where users are able to complete the work faster, able to improve user performance in carrying out their work, able to increase productivity, be able to 
increase effectiveness, be able to simplify the work done. Al-Samadi's (2012) research has proven that perceived usefulness has an effect on attitude in 2012 online banking research.

Perceived ease of use is used in this study as a means that someone's perception of online payment services is easy to use. This ease is felt in accessing online payment services, easy to use and easy to understand.

Based on expert research concluded by Kim et al (2008) shows that the intention to use an e-commerce system is driven by trust which has an important role in increasing the usefulness of e-commerce systems. To achieve the objectives of this research, the researcher develops a concept model. In developing this concept model the variables of usability, convenience and trust are independent variables that influence the dependent variable, namely online purchasing decisions.

Another result of the research conducted by Denni Ardyanto (2015) where the results of his research show that convenience significantly influences online purchasing decisions, trust has a significant effect on online purchasing decisions, ease and trust in using e-commerce has a significant effect on simultaneous online purchasing decisions. The results of the analysis can be seen that with ease in the process of operating transactions affect consumers to use e-commerce services.

The frame of mind in this study is to describe the influence between independent variables and the dependent variable as follows:

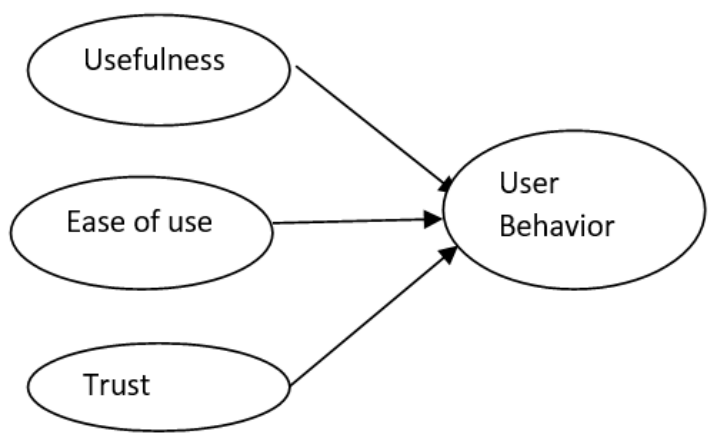

Figure 4

Research Conceptual Framework

\section{Hypothesis}

Based on the hypothesis model above, the hypothesis formulation can be made as follows:

1. There is a significant influence between the use of e-commerce and the behavior of e-commerce users partially.

2. There is a significant influence between the ease of using e-commerce to the behavior of e-commerce users partially.

3. There is a significant influence between the trust in using e-commerce to the behavior of e-commerce users partially..

\section{METHODOLOGY}

\section{Research Method}

This study uses a causal research method which aims to examine the effect, between a variable (Independent / $\mathrm{Xn}$ ) and other variables (Variable Dependent / Yn). In this case it consists of: X1 = Usefulness, X2 = Ease of use, $\mathrm{X} 3=$ Trust and $\mathrm{Y}=$ User Behavior. This research requires testing hypotheses with statistical tests.

\section{Definition of Operational Variables}

Variables are everything that will be the object of observation in a study in the form of a concept that has a variety of values. In this research, independent variables (dependent variables) and dependent variables (dependent variables, independent variables are:

a) Usefulness (X1) as an Independent variable

b) Ease of Use (X2) as an Independent variable

c) Trust (X3) as an Independent variable

d) User Behavior (Y) as a Dependent variable

The Operational Definition The variables used by the author in conducting research compilation are:

1. User Behavior: The dependent variable in this study is User Behavior. Behavior is an action taken by someone. In the context of the use of information systems, behavior is the actual usage of technology (Jogiyanto 2007: 117). In various studies because actual use cannot be observed by researchers who use questions, many real uses are replaced with perceived usage (Davis (1989) uses real use, while igbaria et al (1995) use measurement of perceived use measured as the amount of time used to interact with a 
technology and the frequency of its use.

2. Usefulness: Usability perceptions are defined to what extent a person believes that using a technology will improve his work performance. (Lui and Jamieson: 2003). Where the indicator is to assume the system will be useful for carrying out certain purposes, making the sale and purchase of products more efficient, useful for facilitating buying and selling.

3. Ease of Use: Davis (1989) defines ease of perception as the level at which one believes that the use of information technology is easy and does not require the effort of the user. Individual perceptions of ease of use (perceived ease of use) are the level at which individuals believe that using a particular system will be free of errors. The research was conducted by Andrie Cesario Shomad (2013), Pradita and Zaki (2012), Iwan and Rahmahwati (2014), and Krisnu Putra Yutadi (2014) stating that the perception of ease of use has a positive effect on e-commerce usage interests and behavior. The results of this study are not consistent with the research conducted by Pavlou (2001) which states that perceived ease of use has a insignificant influence on the interest in using e-commerce systems. Sisca (2016) The results of the analysis for this model show that interest in using e-commerce is positively influenced by the construct of perceived ease of use and construct of risk perception. While the construct of perception of fraud in cyberspace has a negative effect on interest in using e-commerce.

4. Trust: Independent variables of trust consist of 3 factors, namely ability, benevolence, and integrity. Ability in this case, how the seller is able to provide, serve, and secure security from other parties. Kindness is the willingness of sellers to provide mutually beneficial satisfaction between themselves and consumers. integrity can be seen from the perspective of fairness, fulfillment, loyalty, honesty, dependability, and reliability.

\section{Populations and Samples}

The population used in this study are all shopee application users. Samples are some of the members of the population selected using certain processes so that they can represent the population. The method of selecting samples used in this study is a convenience sampling method, namely the type of sample selection based on the availability of elements and the ease of obtaining them. Samples are taken / selected because the sample is in the right place and time.

\section{Analysis Method}

Data analysis is a procedure or process of activities withinsummarize the data collected from the results of the study so that the data can be processed into a form that is more understandable to the reader. In this study questionnaire analysis using a Likert scale 1-5, using smartPLS3 software (Partical Least Square version 3).

\section{RESULTS AND DISCUSSION}

Hypothesis testing

\section{a. Convergent Validity Test (Outer Model)}

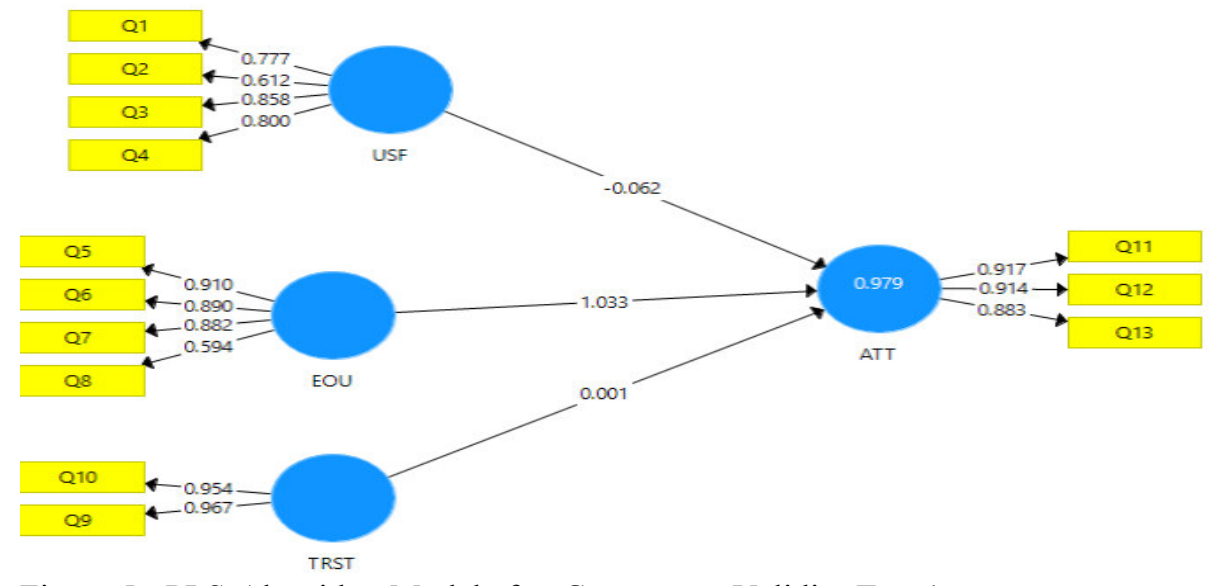

Figure 5 - PLS-Algorithm Model after Convergent Validity Test 1

Source: Primary data processed (2019)

Based on the factor loading value above, it meets convergent validity, the indicator value is above 0.5 .

Another method for assessing discriminant validity is by comparing the square root of average variance extracted (AVE) for each construct with a correlation between constants and other constructs in the model. The model has sufficient discriminant validity if the root AVE for each construct is greater than the correlation 
between other constructs and constructs.

b. Average Variance Extraced (AVE) - (Outer Model)

Table1: Average Variance Extraced

Source: Primary data processed (2019)

\begin{tabular}{|l|l|}
\hline Variabel & AVE \\
\hline Ease Of Use & 0.579 \\
\hline Perilaku Pengguna & 0.777 \\
\hline Trust & 0.895 \\
\hline Usefulness & 0.557 \\
\hline
\end{tabular}

A good model is required if the AVE of each other construct is greater than 0.5 (Ghozali, 2014). The output results in the table above show that the AVE value of all variables is greater than 0.50 .

c. Reliability Test using Composite Realibility and Chronbach Alpha - (Outer Model)

Table 2. PLS Algorithm Models - Composite Realibility and Chronbach Alpha

\begin{tabular}{|l|l|l|}
\hline Variable & $\begin{array}{l}\text { Composite } \\
\text { Reliability }\end{array}$ & $\begin{array}{l}\text { Cronbachs } \\
\text { Alpha }\end{array}$ \\
\hline Ease Of Use & 0.896 & 0.844 \\
\hline User Behaviour & 0.931 & 0.889 \\
\hline Trust & 0.960 & 0.916 \\
\hline Usefulness & 0.849 & 0.770 \\
\hline
\end{tabular}

Source: Primary data processed (2019)

The reliability test output results using Compostie Reliability and Chronbach Alpha both because of Composite Reliablity above 0.70 and Chronbach Alpha above 0.6 so it can be concluded that all construct indicators are reliable or meet reliability testing.

d. R Square Test and Predictive Relevance (Inner Model)

Table 3 PLS Algorithm - R Square \& Predictive Relevance Models

\begin{tabular}{|c|c|}
\hline & R Square \\
\hline User Behaviour & 0.978 \\
\hline
\end{tabular}

Source: Primary data processed (2019)

Based on the determination coefficient in the table above, the $\mathrm{R}^{2}$ value of the User Behavior variable is 0.978, which means that the value can indicate that the User Behavior variable can be explained by the usefulness variable, ease of use and trust by $97.8 \%$. In this study the adjusted $\mathrm{R}^{2}$ is $97.8 \%$ while the remaining $2.2 \%$ is influenced by other variables not found in the research model.

The next test is the Path Coefficient test to see the significance of Usefulness (USF), Ease of Use (EOU), and trust (TRST) against User Behavior (ATT). To test the hypothesis in this study, the $\mathrm{t}$ value of statistics for each pathway is partially directly affected.

The results of this test will show significant results seen from the results of the Original Sample, the value of probability and t-statistics. For probability values, the p-value with alpha is $5 \%$. Tests are carried out with limits according to table $t$. The t-table value for alpha $5 \%$ is 1.96 . to accept the proposed hypothesis is more than 1.96 , which if $\mathrm{t}$ table of significance $5 \%$ is in the range of values -1.96 and 1.96 , the hypothesis will be rejected. The results of $t$-statistical estimation can be seen in the path coefficients.

Table 4: Paht Coefficient

\begin{tabular}{|l|l|l|l|l|l|}
\hline Variable & Original sample & Sample mean & Standar deviasi & T statistics & P values \\
\hline EOU->ATT & 1.033 & 1.033 & 0.023 & 44.311 & 0.000 \\
\hline TRST $->A T T$ & 0.001 & 0.003 & 0.029 & 0.022 & 0.982 \\
\hline USF->ATT & -0.062 & -0.064 & 0.026 & 2.389 & 0.017 \\
\hline
\end{tabular}

Source: Primary data processed (2019)

In the table above, the path parameters obtained from the effect of Usefulness on Behavior (ATT) are 2,389. The value of $t$ statistics is 2.389 greater than the value of $t$ table 1.96 and $\mathrm{P}$ values are 0.017 smaller than the significance level $\alpha=0.05(5 \%)$. These results indicate that there is a significant positive effect between Usefulness to Behavior (ATT). Thus the first hypothesis (H1) which states that Usefulness has a significant effect on Behavior (ATT). acceptable.

For the relationship between the Ease of Use (EOU) variable on behavior (ATT), the results in the table above show path parameter coefficients with a statistical $t$ value of 44.311 greater than $t$ table 1.96 and a $p$ value of 0,000 smaller than the significance level $\alpha=0.05(5 \%)$. These results indicate that there is a significant influence between Ease of Use (EOU) on Behavior (ATT). Thus the second hypothesis (H2) which states that the Ease of Use (EOU) has a significant effect on Behavior (ATT) is acceptable.

For the relationship between trust variable (TRST) on Behavior (ATT) with a t value of 0.022 (smaller than 1.96) and $p$ values at 0.982 (greater than the significance level $\alpha=0.05$. These results indicate that there is no 
significant positive effect between trust (TRST) against Behavior (ATT) Thus the third hypothesis (H3) which states that trust (TRST) has a significant effect on Behavior (ATT) is rejected. These results are consistent with research conducted by budyastuti and iskandar (2018).

\section{CONCLUSION}

From the results of the research above, the researcher can conclude that:

1. Usefulness has a significant effect on user behavior

2. Ease of use has a positive effect on user behavior

3. Trust does not affect user behavior.

\section{References:}

Ardyanto,Denni.dkk. 2015. Pengaruh Kemudahan dan Kepercayaan Menggunakan E-Commerce Terhadap Keputusan Pembelian Online (Survei Pada Konsumen www.petersaysdenim.com). Jurnal Administrasi Bisnis Vol. 22 No. 1 Mei 2015

Bimo Walgito. 2004. Pengantar Psikologi Umum. Yogyakarta: Andi Offset.

Budi. 2010. Sekilas Tentang Technology Acceptance Model (TAM). Artikel. www.statistikakomputasi.wordpress.com. (diakses tanggal 13 november 2015)

Budyastuti, triyani and iskandar, diah. 2018. The Influence of Usefulness, Easy of Use and Trust Using ECommerce To User Behaviour (Case Study To Lazada.Com Consumers). Journal of Marketing and Consumer Research. ISSN 2422-8451. Vol.46

Chuck, L. B. 2002. Welcome to the dark side: how e-commerce, online consumer, and e-mail fraud rely on misdirection and misinformation. AP Mintz. Information Today Inc.

Clough, J. 2010. Principles of cybercrime. Edisi Pertama. Cambridge, UK: Cambridge University Press.

Dailysocial, 2015. Potensi dan Tantangan E-commerce Indonesia tahun 2015. Artikel www.dailysocial.net. Diakses pada tanggal 12 September 2015, 19:35.

Davis, F.D. 1989. Perceived usefulness, perceived ease of use, and user acceptance of information technology. MIS Quarterly. Vol. 13(3). 319-40.

Davis, F.D. 1986. Perceived Usefulness, Perceived Ease of Us, and User Acceptance of Information Technology. MIS Quartely. pp. 319-340.

Engel, James. F. (1995). Perilaku Konsumen. Jakarta : Binapura Aksara.

Erna Ferrinadewi. 2008. Merek \& Psikologi Konsumen. Yogyakarta: Graha Ilmu.

Hartono, Jogiyanto. 2007. Sistem Informasi Keperilakuan. Yogyakarta: Andi.

Heidjen, H., Van Der, V. T., and Creemers, M. 2003. Understanding Online Purchase Intentions: Contributing From Technology and Trust Perspectives. European Journal of Information System. 2003, (12), 41-48.

Hestin Mulyasari, dkk. 2014. Analisis Jenis Sistem Pembayaran Elektronik Dalam Transaksi E-Commerce Di Indonesia. Seminar Nasional Teknologi Informasi dan Komunikasi 2014 (SENTIKA 2014). Yogyakarta, 15 Maret 2014. ISSN: 2089-9813

Hutagaol, J., Darussalam, dan Septriady, Danny. 2006. Kapita Selekta Perpajakan. Jakarta: Penerbit Salemba Empat.

Imam Ghozali. 2012. Structural Equation Modeling - Teori, Konsep dan Aplikasi dengan Program LISREL 8.54. Semarang: Badan Penerbit Universitas Diponegoro.

Imam Ghozali. 2013. Aplikasi Analisis Multivariate dengan Program SPSS. Semarang: Badan Penerbit Universitas Diponegoro.

Imamuddin,Moch. 2014. Pengaruh Persepsi Kemudahan (Perceived Ease Of Use) Dan Persepsi Kegunaan (Perceived Usefulness) Terhadap Penggunaan Aktual (Actual Usage) E-Commerce OLX.co.id. Skripsi. Universitas Pendidikan Indonesia

Jarvenpaa, S., L., Tractinsky, N., dan Vitale, M. 2000. Consumer Trust in An Internet Store. Information Technology and Management. Vol. 1(12), pp. 45-71.

Jati, N., J. 2012. Analisis Faktor-faktor yang Mempengaruhi Minat Pemanfaatan dan Penggunaan Sistem ETicket (Studi Empiris pada Biro Perjalanan di Kota Semarang). Skripsi. Semarang: Program Sarjana Fakultas Ekonomika dan Bisnis Universitas Diponegoro.

Jogiyanto, H.M. 2007. Sistem Teknologi Keperilakuan. Yogyakarta : Andi Offset.

Jogiyanto, H.M. 2011.Konsep dan Aplikasi Struktural Equation Modeling Berbasis Varian dalam Penelitian Bisnis. Yogyakarta: Unit Penerbit dan Percetakan STIM YKPN Yogyakarta.

Kamil, Islamiah. 2017. Faktor-faktor Yang Mempengaruhi Perilaku Penggunaan Sistem E.Commerce (Studi Kasus Pada Mahasswa Universitas Prof. Dr. Moestopo (Beragama)). Jurnal KIA

Kim, DJ, Ferriny, DL \& Rao, HR. 2008. A trust-based consumer decision-making model in electronic commerce: The role of trust, perceived risk, and their antecedents. Decision Support Systems. vol. 44, pp. 544-564.

Laudon, K., Traver, C. 2009. E-Commerce: business, technology, society. Prentice Hall Higher Education. 
Lui, H., K., dan Jamieson, R. 2003. Integrating Trust and Risk Perceptions in Business-to-Consumer Electronic Commerce with The Technology Acceptance Model. In European Conference on Information Systems 2003. Naples.

Nazar, M.R, dan Syahran. 2008. Pengaruh Privasi, Keamanan, Kepercayaan, dan Pengalaman terhadap Niat untuk Bertransaksi secara Online. Program Pasca Sarjana Universitas Gajahmada Yogyakarta.

Niki. 2015. Pengaruh Pengetahuan, Pemahaman dan Kesadaran PPN atas Barang Kena Pajak (BKP) Terhadap Pola Konsumsi Mahasiswa UPDN. Skripsi. Universitas Prof. Dr. Moestopo (Beragama).

Pavlou. 2002. Consumer Intention to Adopt Electronic Commerce Incorporating Trust and Risk in Technology Acceptance Model. Journal of Logistics Information Management.

Pavlou, P.A.2003. Consumer Acceptance of Electronic Commerce: Integrating Trust and Risk with the Technology Acceptance Model. International Journal of Electronic Commerce/ Spring 2003. Vol. 7(3), pp. 69-103.

Perkembangan Sangat Pesat Regulasi E-commerce http: //sp.beritasatu.com/ekonomidanbisnis/perkembangan-sangat-pesat-regulasi-e-commerce-belum-siap/81675. Diakses pada tanggal 19 November 2015, 13:45.

Republika, 2015. Transaksi E-commerce Bisa Capai 312 Triliun. Artikel www.republika.co.id. Diakses pada tanggal 15 September 2015, 19:50.

Rofiq, Ainur. 2007. Pengaruh Dimensi Kepercayaan (Trust) Terhadap Partisipasi Pelanggan E-Commerce (Studi Pada Pelanggan E-Commerce di Indonesia). Skripsi. Universitas Brawijaya Malang.

Saraswati, P., \& Baridwan, Z. 2012. Penerimaan Sistem E-commerce: Pengaruh kepercayaan, Persepsi Manfaat dan Persepsi Risiko. Skripsi. Universitas Brawijaya.

Sekaran, U. 2006. Research Methods For Business: A Skill Building Appoarch. PT. Jakarta: Elex Media Komputindo.

Shomad, A. 2013. Pengaruh Kepercayaan, Persepsi Kegunaan, Persepsi Kemudahan, Dan Persepsi Risiko Terhadap Perilaku Penggunaan E-Commerce. Skripsi. Universitas Brawijaya

Sidharta, Iwan., \& Sidh, Rahmawati. 2012. Pengukuran Persepsi Manfaat dan Persepsi Kemudahan Terhadap Sikap Serta Dampaknya atas Penggunaan Ulang Online Shopping pada E-commerce. Jurnal Computech \& Bisnis. Vol. 8, No.2, pp. 92-100.

Sisca Amalia. 2016. "Pengaruh Perceived of Cyber Fraud, Perceived Ease of Use dan Perceived Risk Terhadap Perilaku Penggunaan Sistem E-commerce". Skripsi. Universitas Mercubuana

Sugiyono. 2014. Metodologi Penelitian Kuantitatif, Kualitatif dan Kombinasi (Mixed Methods). Bandung: Alfabeta.

Syara Mutiara Amalia,Dkk. 2016. Pengaruh Kualitas Sistem Informasi, Kualitas Informasi, Dan Perceived Usefulness Terhadap Kepuasan Pengguna Sistem Informasi Akuntansi (Studi Pada Pengguna Sistem Informasi Akuntansi Di Rumah Sakit Mata Cicendo Bandung). E-Proceeding Of Management : Vol.3, No.2 Agustus 2016

Tjini, S. S. Ayu., \& Baridwan, Z. 2012. Pengaruh Kepercayaan, Persepsi Kegunaan, Persepsi Kemudahan, dan Persepsi Kenyamanan Terhadap Minat Penggunaan Sistem Internet Banking. Skripsi. Universitas Brawijaya.

http://www.tribunnews.com/bisnis/2018/02/08/inilah-evolusi-persaingan-e-commerce-di-indonesia-tahun-2017. Diunggah 8 Februari 2018

Warr, M. 2000. Fear of crime in the United States: avenues for research and policy . Criminal Justice. vol. 4, pp.451-489.

Yutadi, K. 2014. Pengaruh Persepsi Privasi, Persepsi Keamanan, Persepsi Kepercayaan, Persepsi Risiko, Persepsi Kegunaan dan Persepsi Kemudahan Penggunan Terhadap Minat Penggunaan E-Commerce. Skripsi. Universitas Brawijaya.

Zeinab Zaremohzzabieh, Bahaman abu Samah, Mahazan Muhammad, Siti Zobidah Omar, Jusang Bolong, Md Salleh Hassan \& Hayrol Azril Mohamed Shaffril, 2015. A Test of the Technology Acceptance Model for Understanding the ICT Adoption Behavior of Rural Young Entrepreneurs. International Journal of Business and Management. 10(2): h: 158-169.Universitas Nusantara PGRI Kediri. 